\title{
ANALISIS KELAYAKAN USAHA TEMPE DI KELURAHAN BATANG BUNGO KECAMATAN PASAR MUARA BUNGO KABUPATEN BUNGO (STUDI KASUS USAHA TEMPE BAPAK KASDONO)
}

\author{
Hidayati, Syaiful Azhar dan Isyaturriyadhah \\ Program Studi Agribisnis Fakultas Pertanian Universitas Muara Bungo \\ ida taurus18@yahoo.com, isyaturriyadhah amin@yahoo.com
}

\begin{abstract}
ABSTRAK
Penelitian ini dilaksanakan di Kelurahan Batang Bungo Kecamatan Pasar Muara Bungo yaitu pada usaha tempe Bapak Kasdono. Penelitian ini dilaksanakan selama 1 bulan yaitu dari tanggal 16 Maret sampai dengan tanggal 16 April 2017. Alasan pemilihan lokasi ini adalah daerah tersebut pengusaha tempe masih aktif berproduksi dan tingkat produksi yang tinggi. Penelitian ini bertujuan untuk menganalisis pendapatan pengusaha tempe serta untuk mengetahui apakah usaha tempe Bapak Kasdono di Kecamatan Pasar Muara Bungo Kabupaten Bungo masih layak untuk dikembangkan.

Metode Penelitian yang digunakan adalah metode penelitian survey dengan dasar penetapan wilayah secara sengaja karena di Kecamatan Pasar Muara Bungo Kabupaten Bungo terdapat kegiatan usaha tempe yang masih aktif berproduksi, dan pengambilan data dilakukan secara studi kasus. Data yang diperoleh dari dalam penelitian ini disederhanakan dengan melakukan tabulasi kemudian dianalisis secara deskriptif. Analisis yang dilakukan dalam penelitian ini adalah analisis pendapatan, NPV, IRR dan analisis Net B/C.

Hasil penelitian menunjukkan bahwa rata-rata pendapatan yang diperoleh dalam satu bulan proses produksi tempe di daerah penelitian adalah $\mathrm{Rp}$ 19.440.458/bulan. Dilihat dari nilai NPV positif $\mathrm{Rp}$ 1.085.826.816,8, Net B/C 3,42 dan IRR 43,2\%. Dimana nilai Net B/C > 1 dan nilai IRR > suku bunga pinjaman, artinya usaha tempe Bapak Kasdono di Kecamatan Pasar Muara Bungo Kabupaten Bungo layak untuk dikembangkan secara finansial.
\end{abstract}

Kata Kunci: Analisis, Kelayakan, Usaha Tempe

\begin{abstract}
This research was carried out in the Muara Bungo Market District in Bungo District for 1 month, from March 16 to April 16, 2017. The reason for choosing this location was that the tempe entrepreneurs were still actively producing and high production levels. This study aims to analyze the income of tempe entrepreneurs as well as to find out whether Mr Kasdono's tempe business in Pasar Muara Bungo District, Bungo Regency is still feasible to develop. The research method used is a survey research method on the basis of deliberate determination of the area because in Pasar Muara Bungo Subdistrict, Bungo District, there are tempe business activities that are still actively producing, and data collection is carried out in case studies. The data obtained from this study are simplified by tabulating and then analyzed descriptively. The analysis carried out in this study is income analysis, NPV, IRR and Net B / C analysis. The average income obtained in one month of the tempe production process in the study area was Rp. 19,440,458 / month. Judging from the positive NPV value of Rp 1,085,826,816.8, Net B / C 3.42 and IRR 43.2\%. Where the Net B/C > 1 value and IRR value $>$ the loan interest rate, meaning Mr Kasdono's tempe business in Pasar Muara Bungo District, Bungo Regency is worthy to be developed financially.
\end{abstract}

Keywords: analysis, feasibility, tempe business

\section{PENDAHULUAN}

\section{Latar Belakang Masalah}

Agroindustri merupakan perpaduan antara pertanian dan industri, dimana keduanya kemudian menjadi sistem pertanian dengan berbasis industri yang terkait dengan pertanian terutama pada sisi penanganan pasca panen, dan sebagai salah satu sub sistem dari agribisnis yang berfungsi sebagai pengolahan hasil pertanian, baik itu menjadi barang jadi atau setengah jadi, seperti pengolahan kedelai menjadi tempe, tahu, kecap, susu kedelai dan olahan lainnya.

Potensi dan peluang pengembangan aneka olahan kedelai masih terbuka luas sejalan dengan bertambahnya jumlah penduduk, jenis olahan kedelai yang paling popular hingga sekarang adalah tempe dan tahu sebanyak $50 \%$ konsumsi kedelai digunakan untuk pembuatan tempe, $30 \%$ sebagai bahan baku pembuatan tahu dan sisanya olahan lain. Industri pengolahan kedelai dengan proses fermentasi di antaranya pembuatan tempe, 
kecap dan taoco. Beberapa penganan dengan bahan baku tempe di antaranya keripik tempe dan burger tempe (Warisno dan Dahana, 2010).

Tempe adalah olahan kedelai yang sangat diminati oleh berbagai kalangan umur, selain itu tempe juga memiliki kandungan gizi yang tinggi dan mempunyai beberapa manfaat yaitu : makanan yang berkadar protein tinggi yaitu sekitar $20 \%$, makanan sebagai sumber vitamin $\mathrm{B}_{12}$ yang esensial baik untuk kaum vegetarian, makanan yang berkadar lemak rendah dan berdaya cerna tinggi, selain itu sebagai makanan alternatif sumber protein yang baik dengan harga relatif murah dan terjangkau dibandingkan dengan sumber protein hewani seperti daging, susu dan telur (Cahyadi, 2012).

Usaha Tempe Bapak Kasdono adalah salah satu usaha yang ada di Kelurahan Batang Bungo, usaha ini sudah dijalankan selama 33 tahun. Ini berarti dapat diasumsikan bahwa usaha tempe dapat dikembangkan menjadi usaha yang lebih bersifat komersil dengan tujuan utama mencari keuntungan. Untuk melihat kemungkinan pengembangan usaha perlu dipelajari mengenai studi kelayakan usaha ini.

Masalah yang dihadapi para pengusaha, selain keterbatasan modal juga keterbatasan sumber daya alam dalam melihat prospek usaha/proyek yang dikembangkan. Bertitik tolak pada permasalahan tersebut, untuk meningkatkan peranan para pengusaha ekonomi lemah seperti usaha tempe ini, dalam mengatasi masalah permodalan diperlukan peningkatan sumber daya melalui studi kelayakan bisnis.

Dengan meneliti studi kelayakan usaha tempe ini diharapkan dapat memberikan informasi seberapa jauh usaha tersebut mampu menutupi segala kewajiban serta prospeknya di masa yang akan datang apakah usaha ini layak atau tidak untuk dikembangkan. Bagi pemilik modal, melalui studi kelayakan mereka dapat mengetahui prospek perusahaan dan kemungkinan-kemungkinan keuntungan yang akan diterima. Pengertian layak dalam hal ini adalah kemungkinan dari gagasan usaha/proyek yang akan dilaksanakan memberikan manfaat, khususnya dalam arti manfaat ekonomi. Dilihat dari aspek ekonomis, usaha tempe merupakan bisnis yang sangat menguntungkan. Peluang pasar dalam negeri maupun ekspor untuk komoditi ini masih sangat terbuka. Hal ini dikarenakan tempe merupakan konsumsi seharihari masyarakat sehinga permintaan untuk tempe relatif stabil bahkan cenderung mengalami kenaikan.

Usaha Tempe Bapak Kasdono merupakan usaha perorangan yang didirikan oleh Bapak Kasdono yang terletak di Lorong Garuda RT 02 RW 01 Kelurahan Batang Bungo Kecamatan Pasar Muara Bungo Kabupaten Bungo. Produk jadi yang dihasilkan oleh usaha ini berupa tempe dengan beberapa macam kemasan dan ukuran seperti kemasan daun ukuran besar, daun panjang, plastik panjang, plastik menengah dan plastik tipis dengan harga yang berbeda-beda. Pada saat ini usaha tempe Bapak Kasdono telah mempekerjakan 3 orang karyawan yang membantu dalam proses produksi tempe, ketiga karyawan tersebut diberi upah dengan sistem bulanan.

\section{Rumusan Masalah}

Berdasarkan uraian pada latar belakang di atas, maka permasalahan yang akan diteliti dalam penelitian ini adalah :

1. Berapa besar tingkat pendapatan yang diperoleh produsen usaha tempe Bapak Kasdono di Kelurahan Batang Bungo Kecamatan Pasar Muara Bungo Kabupaten Bungo?

2. Bagaimana tingkat kelayakan usaha tempe Bapak Kasdono di Kelurahan Batang Bungo Kecamatan Pasar Muara Bungo Kabupaten Bungo?

\section{Tujuan dan Kegunaan Penelitian}

Tujuan dari penelitian ini yaitu untuk mengetahui tingkat pendapatan produsen usaha tempe Bapak Kasdono di Kelurahan Batang Bungo Kecamatan Pasar Muara Bungo Kabupaten Bungo, dan untuk mengetahui apakah usaha tempe adalah usaha yang menguntungkan dan layak untuk diusahakan oleh produsen tempe di Kelurahan Batang Bungo di Kecamatan Pasar Muara Bungo Kabupaten Bungo.

Kegunaan penelitian ini yaitu sebagai media informasi bagi pihak yang terkait dalam pengembangan usaha tempe, serta sebagai bahan pertimbangan bagi pemerintah maupun lembaga lain dalam mengambil kebijakan khususnya dalam bidang yang berkaitan dengan usaha tempe.

\section{Kerangka Pemikiran}

Kerangka pemikiran diilustrasikan dalam gambar 1 berikut:

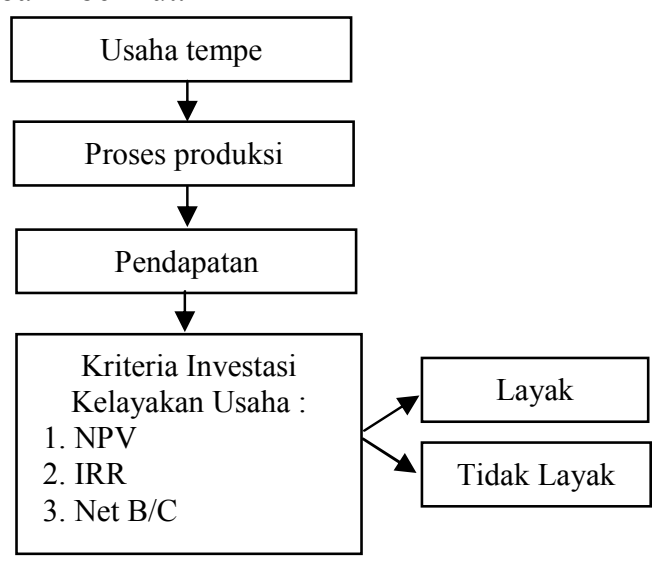

Gambar 1. Skema Kerangka Pemikiran 


\section{Hipotesis Penelitian}

Hipotesis penelitian ini yaitu (1) Diduga tingkat pendapatan produsen usaha tempe Bapak Kasdono di Kelurahan Batang Bungo Kecamatan Pasar Muara Bungo Kabupaten Bungo tinggi, (2) Diduga usaha tempe Bapak Kasdono di Kelurahan Batang Bungo Kecamatan Pasar Muara Bungo Kabupaten Bungo layak untuk dikembangkan.

\section{METODE PENELITIAN}

Metode penelitian ini menggunakan metode survey, yaitu dengan cara pengamatan langsung ke lokasi penelitian dan menggunakan kuesioner sebagai alat pengumpulan data yang pokok (Harnanto, 1991). Penelitian dilakukan dengan beberapa tahapan, yaitu pengumpulan data hasil survey dan analisis data, pengujian hipotesis, serta menarik kesimpulan. Jumlah pengusaha tempe di daerah penelitian sebanyak 1 orang, sehingga penelitian ini merupakan penelitian studi kasus dan pengambilan data dilakukan secara sensus yaitu menggunakan semua anggota populasi sebagai sampel.

Dari data penelitian yang telah dikumpulkan, ditabulasi dan dianalisis dengan metode kuantitatif, sedangkan untuk menghitung besarnya tingkat pendapatan digunakan rumus sebagai berikut (Suratiyah, 2006) :

\section{a. Analisis Pendapatan}

$$
T R=Y x P y
$$

Dimana TR $=$ Total penerimaan $(\mathrm{Rp})$

$$
\text { Py = Harga Produk (Rp) }
$$$$
\mathrm{Y}=\text { Jumlah Produksi }(\mathrm{Kg})
$$

$$
T C=F C+V C
$$

Dimana $\mathrm{TC}=$ Total biaya $(\mathrm{Rp})$

$$
\mathrm{FC}=\text { Total Biaya tetap (Rp) }
$$$$
\mathrm{VC}=\text { Total Biaya Variabel }(\mathrm{Rp})
$$$$
Y=T R-T C
$$

Dimana $\mathrm{Y}=$ Pendapatan $(\mathrm{Rp})$

$\mathrm{TR}=$ Total penerimaan $(\mathrm{Rp})$

$\mathrm{TC}=$ Total biaya (Rp)

\section{b. Analisis Kelayakan}

\section{Analisis NPV}

$$
\underset{i=1}{N P} V=\sum_{i} N B(1+i)^{-n}
$$

$$
\begin{aligned}
\text { Dimana NB } & =\text { Net Benefit }=\text { Benefit }- \text { Cost } \\
\mathrm{i} & =\text { Discount faktor } \\
\mathrm{n} & =\text { tahun (waktu) }
\end{aligned}
$$

Jika NPV $>0$ dikatakan usaha tersebut feasible untuk dilaksanakan dan jika NPV $<0$ tidak layak untuk dilaksanakan dan apabila $\mathrm{NPV}=0$ berarti usaha tersebut berada dalam keadaan break even point (BEP).

\section{Analisis IRR}

$$
I R R=i_{1}+\frac{N P V_{1}}{\left(N P V_{1}-N P V_{2}\right)} x\left(i_{2}-i_{1}\right)
$$

Dimana :

$\mathrm{i}_{1}=$ tingkat discount rate yang menghasilkan $\mathrm{NPV}_{1}^{+}$

$\mathrm{i}_{2}=$ tingkat discount rate yang menghasilkan $\mathrm{NPV}_{2}^{+}$

Jika nilai IRR yang didapat lebih tinggi dari tingkat suku bunga yang berlaku maka usaha tersebut layak untuk diusahakan, maka sebaliknya jika nilai IRR yang didapat lebih rendah dari tingkat suku bunga yang berlaku maka usaha tersebut tidak layak untuk duusahakan, (Husnan dan Suwarsono, 2000).

$$
\begin{aligned}
& \text { Analisis Net } \mathbf{B} / \mathbf{C} \text { Ratio } \\
& \text { Net } B / C=\frac{\sum_{i=1} N B_{l}(+)}{\sum_{i=1}^{n} N B_{I}(-)}
\end{aligned}
$$

Jika nilai Net $\mathrm{B} / \mathrm{C}>1$, berarti gagasan usaha tersebut layak untuk dikerjakan dan jika Net B/C < 1 berarti tidak layak untuk dikerjakan dan untuk Net $\mathrm{B} / \mathrm{C}=1$ berarti berada dalam keadaan break even point (BEP).

\section{HASIL DAN PEMBAHASAN}

Proses produksi pengolahan kedelai menjadi tempe yang dilakukan pada usaha tempe Bapak Kasdono ada beberapa tahap dapat dilihat pada gambar 2. berikut ini:

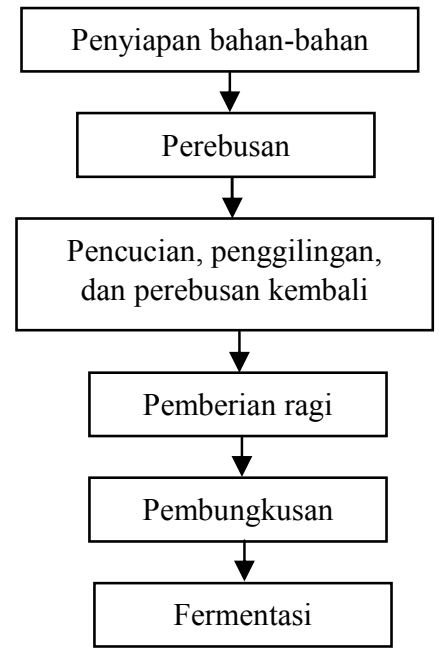

Gambar 2. Proses Pengolahan Kedelai menjadi tempe pada usaha Tempe Bapak Kasdono

Penyiapan bahan yang diperlukan seperti kedelai dan ragi; Perebusan kedelai selama 1,5 jam, proses perebusan sebanyak 5 kali dengan jumlah 
air yang digunakan 2-2,5 liter air untuk $1 \mathrm{~kg}$ kedelai, setelah mendidih diangkat dan direndam dalam air bersih maksimum selama dua hari; Pencucian, penggilingan dan perebusan kembali; kedelai dicuci hingga bersih lalu digiling dengan mesin penggiling kemudian direbus kembali hingga lunak selama 20-30 menit dan ditiriskan; Pemberian ragi tempe (inokulasi), taburkan ragi tempe yang sudah dipersiapkan untuk $10 \mathrm{~kg}$ kedelai diperlukan ragi tempe sekitar 200 gram; Pembungkusan, plastik dan daun pisang yang digunakan untuk membungkus sebaiknya ditusuktusuk menggunakan jarum sehingga terdapat lubang untuk sirkulasi udara, bungkus biji kedelai yang telah diberi ragi dengan plastik atau daun pisang, lalu; Fermentasi, dilakukan dengan meletakkan bakal tempe yang sudah dibungkus di rak kayu atau bambu, proses ini dilakukan sekitar 3 hari atau hingga tempe siap olah.

Analisis biaya produksi dilakukan pada usaha tempe untuk mengetahui berapa besar biaya yang dikeluarkan dan penerimaan yang diperoleh dari kegiatan usaha tempe di tempat penelitian tersebut, biaya produksi padausaha tempe ini adalah biaya yang dikeluarkan oleh pengusaha selama memproduksi tempe. Secara umum biaya produksi ini terdiri atas 2 jenis yaitu Biaya Variabel dan Biaya Tetap.

Biaya variabel yang terdapat pada usaha tempe terdiri dari biaya input, biaya input adalah biaya yang dikeluarkan untuk memperoleh masukan produksi dalam usaha tempe tersebut. Biaya input yang digunakan dalam usaha tempe adalah biaya bahan baku (kedelai), ragi, plastik, daun pisang, dan gas. Rata-rata besarnya biaya variabel pada usaha tempe Bapak Kasdono dapat dilihat pada tabel 1.

Tabel 1. Distribusi Frekwensi dan Presentase Pengusaha Berdasarkan Rata-rata Biaya Variabel per Satu Bulan Produksi pada Usaha Tempe di Daerah Penelitian Tahun 2017

\begin{tabular}{|c|l|r|r|}
\hline No & Biaya Variabel & Nilai (Rp) & $\begin{array}{c}\text { Presentase } \\
\text { (\%) }\end{array}$ \\
\hline 1. & Kedelai & 20.000 .000 & 75,6 \\
2. & Ragi & 250.000 & 0,9 \\
3. & Plastik & 3.750 .000 & 14,2 \\
4. & Daun Pisang & 1.187 .500 & 4,5 \\
5. & Gas & 1.250 .000 & 4,8 \\
\hline \multicolumn{2}{|c|}{ Jumlah } & $\mathbf{2 6 . 4 3 7 . 5 0 0}$ & $\mathbf{1 0 0}$ \\
\hline
\end{tabular}

Sumber : Hasil Olah Data Penelitian 2017

Dari tabel 1 di atas terlihat bahwa rata-rata biaya terbesar yang dikeluarkan oleh pengusaha adalah pada biaya bahan baku kedelai yaitu $\mathrm{Rp}$ 20.000 .000 ,- atau $75,6 \%$ dari total biaya yang dikeluarkan, kedua adalah pada biaya plastik sebesar Rp 3.750.000, dan biaya terbesar ketiga adalah pada biaya gas yaitu sebesar Rp 1.250.000,- sedangkan biaya terendah adalah pada biaya ragi yaitu sebesar Rp 250.000,- atau sebesar 0,9\%.

Biaya tetap yang terdapat pada usaha tempe Bapak Kasdono adalah penyusutan alat yang terdiri dari mesin giling, rak, kre, kompor, drum plastik, drum kaleng, baskom, ember, panci plastik, keranjang, gayung, pisau, alat pelubang ditambah biaya listrik, biaya transportasi dan tenaga kerja. Pada penyusutan alat, perhitungan dilakukan dengan rumus penyusutan alat metode garis lurus, yaitu harga awal dikurang harga akhir dibagi nilai ekonomis alat dikali umur pakai alat dikali jumlah alat. Untuk penentuan usia ekonomis didasarkan atas ketahanan alat dan penggunaan alat. Rata-rata besarnya biaya tetap yang digunakan dalam usaha tempe Bapak Kasdono dilihat pada tabel 2.

Tabel 2. Distribusi Frekwensi dan Presentase Pengusaha Berdasarkan Rata-rata Biaya Tetap per Satu Bulan Produksi pada Usaha Tempe di Daerah Penelitian Tahun 2017

\begin{tabular}{|c|l|r|r|}
\hline No & \multicolumn{1}{|c|}{ Uraian } & \multicolumn{1}{c|}{$\begin{array}{c}\text { Nilai } \\
\text { (Rp) }\end{array}$} & $\begin{array}{c}\text { Presentase } \\
(\mathbf{\%})\end{array}$ \\
\hline 1. & Penyusutan Alat & & \\
& - Mesin giling & 69.990 & 1,02 \\
& - Rak & 8.148 & 0,1 \\
& - Kre & 92.595 & 1,34 \\
& - Kompor & 9.999 & 0,15 \\
& - Drum plastik & 12.222 & 0,17 \\
& - Drum kaleng & 2.667 & 0,03 \\
& - Baskom & 3.750 & 0,05 \\
& - Ember & 1.041 & 0,02 \\
& - Panci plastik & 1.041 & 0,02 \\
& - Keranjang & 37.500 & 0,56 \\
& - Gayung & 624 & 0,01 \\
& - Pisau & 1.800 & 0,03 \\
& - Alat pelubang & 665 & 0,01 \\
\hline 2. & Listrik & 350.000 & 5,07 \\
\hline 3. & Trasportasi & 300.000 & 4,35 \\
\hline 4. & Tenaga Kerja & 6.000 .000 & 87,05 \\
\hline \multicolumn{2}{|l|}{ Jumlah } & $\mathbf{6 . 8 9 2 . 0 4 2}$ & $\mathbf{1 0 0 , 0 0}$ \\
\hline Sumber : Hasil Olah Data Penelitian 2017 &
\end{tabular}

Dari tabel 2 diketahui bahwa rata-rata biaya tetap yang terbesar pada usaha tempe Bapak Kasdono adalah pada biaya tenaga kerja yaitu sebesar Rp 6.00.000,- atau sebesar 87,05\% biaya dihitung per satu kali produksi yaitu selama 25 hari. Dan jumlah biaya tetap per satu bulan produksi pada usaha tempe Bapak Kasdono adalah sebesar Rp 6.892.042,-. Pada usaha tempe Bapak Kasdono biaya penyusutan alat adalah total dari biaya penyusutan alat yang digunakan, yaitu mesin giling, rak, kre, kompor, drum plastik, drum kaleng, baskom, ember, panci plastik, keranjang, gayung, pisau dan alat pelubang.

Biaya total adalah semua biaya yang dibutuhkan untuk melaksanakan usaha yang dihitung dengan menjumlahkan biaya tetap dan 
biaya variabel. Rata-rata jumlah biaya total dapat dilihat pada tabel 3 .

Tabel 3. Distribusi Frekwensi dan Presentase Pengusaha Tempe Berdasarkan Ratarata Biaya Total pada Usaha Tempe Bapak Kasdono Tahun 2017

\begin{tabular}{|c|l|r|r|}
\hline No & \multicolumn{1}{|c|}{ Uraian } & \multicolumn{1}{c|}{ Nilai (Rp) } & $\begin{array}{c}\text { Presentase } \\
\text { (\%) }\end{array}$ \\
\hline 1. & Biaya Variabel & 26.437 .500 & 79,3 \\
2. & Biaya Tetap & 6.892 .042 & 20,7 \\
\hline \multicolumn{2}{|c|}{ Jumlah } & $\mathbf{3 3 . 3 2 9 . 5 4 2}$ & $\mathbf{1 0 0}$ \\
\hline
\end{tabular}

Sumber : Hasil Olah Data Penelitian 2017

Dari tabel 3 diatas diketahui bahwa rata-rata biaya total yang dibutuhkan untuk usaha tempe per satu bulan produksi sebesar Rp 33.329.542,-. Jika dilihat dari perbandingan antara biaya variabel dengan biaya tetap yang diperoleh dari penelitian ini, ternyata memang terbukti dalam suatu usaha tempe ini biaya yang terbesar adalah biaya variabel yaitu sebesar Rp 26.437.500,- atau sebesar 79,3\%.

Penerimaan adalah nilai uang yang diperoleh pengusaha dari hasil jumlah produksi yang dihasilkan dengan satuan harga produksi. Sehingga diketahui bahwa besar kecilnya penerimaan sangat ditentukan oleh jumlah produksi yang dihasilkan dan harga jual produksi tersebut. Untuk lebih jelasnya mengenai tentang penerimaan ini dapat dilihat pada tabel 4.

Tabel 4. Rata-rata Penerimaan pada Usaha Tempe Bapak Kasdono per Satu Bulan Produksi Tahun 2017

\begin{tabular}{|c|l|r|r|c|}
\hline $\begin{array}{c}\mathbf{N} \\
\mathbf{0}\end{array}$ & \multicolumn{1}{|c|}{ Uraian } & $\begin{array}{c}\text { Jumlah } \\
\text { Produksi } \\
\text { (Bks) }\end{array}$ & $\begin{array}{c}\text { Harga } \\
\text { Satuan } \\
\text { (Rp) }\end{array}$ & $\begin{array}{c}\text { Jumlah } \\
\text { (Rp) }\end{array}$ \\
\hline 1 & $\begin{array}{l}\text { Tempe daun } \\
\text { besar }\end{array}$ & 9.750 & 4.000 & 39.000 .000 \\
\hline 2 & $\begin{array}{l}\text { Tempe daun } \\
\text { panjang }\end{array}$ & 2.500 & 1.200 & 3.000 .000 \\
\hline 3 & $\begin{array}{l}\text { Tempe plastik } \\
\text { panjang }\end{array}$ & 3.000 & 2.500 & 7.500 .000 \\
\hline 4 & $\begin{array}{l}\text { Tempe plastik } \\
\text { menengah }\end{array}$ & 750 & 1.800 & 1.350 .000 \\
\hline 5 & $\begin{array}{l}\text { Tempe plastik } \\
\text { tipis }\end{array}$ & $2.500 *$ & 2.000 & 1.650 .000 \\
\hline \multicolumn{4}{|c|}{ Jumlah } & $\mathbf{5 2 . 5 0 0 . 0 0 0}$ \\
\hline
\end{tabular}

Perhitungan pendapatan pengusaha tempe dapat dilihat pada tabel 5 .

Tabel 5. Rata-rata Pendapatan per Satu Bulan Produksi pada Usaha Tempe Bapak Kasdono Tahun 2017

\begin{tabular}{|c|l|r|}
\hline No & \multicolumn{1}{|c|}{ Uraian } & Nilai (Rp) \\
\hline 1. & Penerimaan (a) & 52.500 .000 \\
2. & Biaya Total (b) & 33.329 .542 \\
3. & Pendapatan (c) $=(\mathrm{a}-\mathrm{b})$ & 19.170 .458 \\
\hline
\end{tabular}

Sumber : Hasil olah Penelitian 2017

Dari tabel 5 diketahui bahwa rata-rata penerimaan yang diperoleh dari usaha tempe Bapak Kasdono yaitu sebesar Rp 52.500.000,- dan ternyata pendapatan yang diperoleh sebesar $\mathrm{Rp}$
19.170.458-, sehingga terbukti bahwa penerimaan yang besar selalu diikuti dengan pendapatan yang diperoleh dari usaha tempe Bapak Kasdono tersebut juga akan besar.

Analisis kelayakan usaha tempe Bapak Kasdono dilakukan untuk mengetahui bagaimana kelayakan usaha tempe yang dijalankan oleh pengusaha di daerah penelitian secara finansial. Untuk mengetahui kelayakan usaha secara finansial usaha tempe Bapak Kasdono digunakan kriteria kelayakan NPV, Net B/C dikenal sebagai perbandingan antara keuntungan dan biaya, dan IRR yaitu perbandingan dengan tingkat suku bunga yang berlaku. Tingkat kelayakan usaha tempe Kasdono dapat dilihat pada tabel 6 .

Tabel 6. Keuntungan, Net B/C dan IRR dan NPV Usaha Tempe Bapak Kasdono Tahun 2017

\begin{tabular}{|c|l|r|}
\hline No & \multicolumn{1}{|c|}{ Uraian } & \multicolumn{1}{|c|}{ Rp/tahun } \\
\hline 1. & Total keuntungan & $278.984 .668,2$ \\
\hline 2. & Net B/C (\%) & 3,42 \\
\hline 3. & IRR (\%) & 43,2 \\
\hline 4. & NPV & $1.085 .826 .816,8$ \\
\hline
\end{tabular}

Sumber : Hasil Olah Data Penelitian 2017

Dari tabel 6 dapat diketahui bahwa tingkat kelayakan suatu usaha untuk dilaksanakan pada diskon faktor $9 \%$ sesuai dengan suku bunga pinjaman di daerah penelitian. Untuk usaha tempe Bapak Kasdono diperoleh nilai Net B/C adalah 3,42 . Sesuai dengan kriteria apabila nilai Net $B / C$ $>1$ maka usaha tersebut layak untuk dikembangkan. Untuk mengetahui kelayakan Internal Rate of Return (IRR) dapat diketahui dengan menghitung nilai IRR. Nilai IRR yang diperoleh di daerah penelitian adalah 43,2\%, dimana suku bunga pinjaman yang berlaku sebesar 9\% maka IRR > suku bunga pinjaman bank, dengan demikian usaha tempe Bapak Kasdono menguntungkan dan layak untuk dikembangkan secara finansial. Sedangkan nilai NPV Rp 1.085.826.816,8, dengan demikian hipotesis yang menyatakan usaha tempe Bapak Kasdono di Kecamatan Pasar Muara Bungo Kabupaten Bungo layak untuk dikembangkan diterima.

\section{PENUTUP}

Kesimpulan

Dari hasil penelitian usaha tempe Bapak Kasdono di Kecamatan Pasar Muara Bungo Kabupaten Bungo mendapat keuntungan sebesar Rp 19.170.485,- per satu bulan produksi.

Dilihat dari nilai NPV Rp 1.085.826.816,8, Net B/C 3,42 dan IRR 43,2\%. Dimana nilai Net $\mathrm{B} / \mathrm{C}>1$ dan nilai IRR > suku bunga pinjaman, artinya usaha tempe Bapak Kasdono di Kecamatan Pasar Muara Bungo Kabupaten Bungo layak untuk dikembangkan secara finansial. 


\section{Saran}

Perlu diperhatikan oleh pengusaha tempe di Kecamatan Pasar Muara Bungo Kabupaten Bungo dalam menekan biaya-biaya produksi terutama biaya variabel agar terjadi keefisienan dalam pemakaian biaya produksi dan mendapatkan pendapatan yang lebih tinggi lagi.

\section{DAFTAR PUSTAKA}

Cahyadi, W. 2012. Kedelai Khasiat dan Teknologi. Bumi Aksara. Jakarta.

Harnanto. 1991. Akuntansi Biaya untuk Perhitungan HPP. BPFE. Jakarta.

Husnan, S dan M. Suwarsono. 2000. Studi Kelayak Proyek Edisi keempat, UPP AMP YKPN Yogyakarta. Yogyakarta.

Suratiyah, K,. 2006. Ilmu Usahatani. Penebar Swadaya. Jakarta.

Warisno dan Dahana. 2010. Meraup Untung dari Olahan Kedelai. PT. Agromedia Pustaka. Jakarta.
Untuk pemerintah perlu memperhatikan perkembangan pengusaha tempe agar dapat berkembang dengan baik dan mendapatkan keuntungan yang lebih. 